\title{
Recent studies on probiotics as beneficial mediator in aquaculture: a review
}

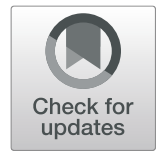

Kazi Nurul Hasan ${ }^{1 *}$ and Goutam Banerjee ${ }^{2}$

\begin{abstract}
Background: The diseases in fish and other economic aquatic species is a great concern, and every year it causes a huge loss in aquaculture sectors. The use of probiotics might be a good option to reduce the disease risk and to enhance the productivity.

Methods: We have gathered information from various important research and review articles related to fish diseases, probiotics, and gut microbial community. We have tried our level best to represent the up-to-date information in a concise manner.

Results: In this present review, we have demonstrated the various beneficial aspects of probiotics in aquaculture sectors. Probiotics are considered as novel functional agents that have potential implications in influencing the gut microbiota of any aquatic organism. Researchers have already documented that probiotics play a wide spectrum functions (such as decrease diseases and stress, enhance immunity, modulate gut microbiota, helps in nutrition, improve water quality, etc.) in host body. Furthermore, the beneficial effects of probiotics contribute to increase feed value and growth of the animal, and improve spawning and hatching rate in aquaculture system. Here, we have discussed each and every functions of probiotics and tried to correlate with the previous knowledge.

Conclusion: The reports regarding the efficacy of probiotics and its detailed mechanism of action are scarce. Till date, several probiotics have been reported; however, their commercial use has not been implicated. Most of the studies are based on laboratory environment and thus the potentiality may vary when these probiotics will be used in natural environments (pond and lakes).
\end{abstract}

Keywords: Probiotics, Aquaculture, Antibiotics, Stress, Reproduction, Gut microbiota, Mucosal immunity

\section{Background}

Aquaculture is the fastest growing food industry in several countries like China, India, Norway, etc. According to Food and Agriculture Organization (FAO), the aquaculture production reached 106 million tonnes with an estimated cost of USD 163 \$ in the year 2017 with a growth rate of 6.6. The production/captured of finfish was recorded to be highest in Asian countries, followed by Americans countries, Europe, and Africa. Aquatic animals maintain a close relationship with their external environment, which enhance the risk of diseases susceptibility (Banerjee \& Ray, 2017). Furthermore, high stocking density,

\footnotetext{
*Correspondence: kazihasan5@gmail.com

'Department of Zoology, Sidho-Kanho-Birsha University, Purulia 723104, India Full list of author information is available at the end of the article
}

water pollution, insecticides containing agricultural drainage water, and unscientific feeding enhance the risk of bacterial, fungal, and viral diseases in cultured animals (Banerjee \& Ray, 2017). In intensive culture system, disease outbreak is a major difficulty that decreases the profit in food industries, as well as hampers the socio-economic condition of the country (Bondad-Reantaso et al., 2005).

The use of antibiotics in aquaculture as a preventive measure associated with the evolution and spread of several resistant human pathogens like Aeromonas sp., Escherichia tarda, Escherichia coli, Vibrio vulnificus, Vibrio parahaemolyticus, Vibrio cholerae, and many more (Allameh et al., 2016; Brogden et al., 2014). In a review, Lakshmi, Viswanath, and Sai Gopal (2013) have provided the information regarding the resistance

\section{Springer Open}

(c) The Author(s). 2020 Open Access This article is licensed under a Creative Commons Attribution 4.0 International License, which permits use, sharing, adaptation, distribution and reproduction in any medium or format, as long as you give appropriate credit to the original author(s) and the source, provide a link to the Creative Commons licence, and indicate if changes were made. The images or other third party material in this article are included in the article's Creative Commons licence, unless indicated otherwise in a credit line to the material. If material is not included in the article's Creative Commons licence and your intended use is not permitted by statutory regulation or exceeds the permitted use, you will need to obtain permission directly from the copyright holder. To view a copy of this licence, visit http://creativecommons.org/licenses/by/4.0/. 
development in aquatic pathogens under long-term antibiotic pressure (Lakshmi et al., 2013). Thus, the uses of certain antibiotics in aquaculture industries have been restricted in several countries like the USA and Canada. So, the use of probiotics along with dietary supplementation is a very fruitful strategy to combat pathogenic agents through a variety of mechanisms as an alternative driving force of antibiotic treatment (Bandyopadhyay et al., 2015; Wu, Jiang, Ling, \& Wang, 2015). The term 'probiotic' came from Greek words 'pro' (= favor) and 'bios' (= life) which are live organisms (usually bacteria or yeast or combination of both) and taken with food to confer beneficial effects to host in various ways (Fuller, 1989). The concept of probiotics, in the field of aquaculture, is fundamentally different from those which are used in terrestrial organisms depending upon certain critical influencing factors. It is now well established that probiotics play a vital role in maintaining the gut health by modulation of microbial community structure (Nayak, 2010). The microbes also proliferate independently of the host animal in response to diseases (BondadReantaso et al., 2005; Irianto \& Austin, 2002). The first experimental attempt of the probiotic application in aquaculture was made by Kozasa (1986), considering the beneficial effects of probiotics on humans and poultry (Kozasa, 1986). The rapid evolution of probiotics in aquaculture is well established due to the adverse effects of widely used antibiotics and broad spectrum chemicals which kill most of the beneficial bacteria along with the pathogenic bacteria to the aquatic species (Lakshmi et al., 2013). Additionally, probiotics also work through different mechanisms in aquaculture system to eliminate the organic wastes and pollutants, as a result of incorporation of 'bioremediation' and 'biocontrol' when dealing with the environmental problems. In this context, probiotics can play an effective role in aquaculture production by providing greater non-specific disease protection as well as pollution free water sources (Nandi, Banerjee, Dan, Ghosh, \& Ray, 2018; Panigrahi, Kiron, Satoh, \& Watanabe, 2010). The goal of this review is to summarize and evaluate the current information on the efficacy and mechanism of action of probiotics for the enumeration in a complex microbial community in aquaculture.

\section{Main text}

\section{Application methods of probiotics}

Based on the mode of action, probiotics can be divided into two broad categories: (a) gut probiotics: which are administrated orally along with food to improve the gut associated beneficial microbial flora (Table 1) and, (b) water probiotics: these types of agents proliferate in water medium and exclude the pathogenic bacteria from the specific medium by consuming all available nutrients, resulting in elimination of the pathogenic bacteria through starvation (Table 2).

\section{Candidates as probiotics}

Recently, the application of probiotics is a very popular practice in aquaculture sectors and it is mainly isolated from fish gut. Among several bacterial candidates, lactic acid bacteria (LAB), Bifidobacterium, and Streptococcus (Giri et al., 2013) gain more popularity. Despite the fact that implication of probiotics is relatively a very new approach but it has gained attention due to their potential activity in controlling different physiological activities of aquatic organisms. Thereafter, many probiotics such as Aeromonas media, Bacillus subtilis, Lactobacillus helveticus, Enterococcus faecium, Carnobacterium inhibens,

Table 1 Gut probiotics and their beneficiary effects on aquatic organisms

\begin{tabular}{|c|c|c|}
\hline Name of the probiotics & Beneficial effects & Reference(s) \\
\hline Lactobacillus rhamnosus & $\begin{array}{l}\text { Enhance immunity and reduce disease } \\
\text { susceptibility }\end{array}$ & $\begin{array}{l}\text { Nikoskelainen, Ouwehand, Bylund, Salminen, and } \\
\text { Lilius (2003) }\end{array}$ \\
\hline Lactobacillus plantarum & Enhance stress tolerance & Taoka, Yuge, Maeda, and Koshio (2008) \\
\hline Lactobacillus rhamnosus & Improve blood quality & Panigrahi et al. (2010) \\
\hline Streptococcus sp. & Improve feeding efficiency and growth rate & Lara-Flores and Olvera-Novoa (2013) \\
\hline Bacillus subtilis & Enhance cellular immunity & Sánchez-Ortiz et al. (2015) \\
\hline $\begin{array}{l}\text { Bacillus subtilis + Lactococcus lactis + } \\
\text { Saccharomyces cerevisiae }\end{array}$ & $\begin{array}{l}\text { Enhance survival rate, foster metabolism, } \\
\text { enhance weight }\end{array}$ & Abareethan and Amsath (2015) \\
\hline Bacillus amyloliquefaciens & Enhance antibody concentration, reduce stress & Nandi et al. (2018) \\
\hline Bacillus subtilis + Lactobacillus rhamnosus & Enhance the food digestibility & Munirasu, Ramasubramanian, and Arunkumar (2017) \\
\hline Lactobacillus sp. & $\begin{array}{l}\text { Reduce pathogen load, provide protection } \\
\text { against Aeromonas hydrophilla }\end{array}$ & He et al. (2017) \\
\hline Bacillus cereu & Protect from Aeromonas hydrophilla infection & Dey, Ghosh, and Hazra (2018) \\
\hline $\begin{array}{l}\text { Different species of Bacillus, Arthrobacter, } \\
\text { Paracoccus, Acidovorax etc }\end{array}$ & Reduce pathogen load and provide nutrients & Nandi et al. (2018) \\
\hline Alcaligenes sp. AFG22 & Enhance volatile short chain fatty acids & Asaduzzaman et al. (2018) \\
\hline
\end{tabular}


Table 2 Water probiotics and their role in maintaining water quality

\begin{tabular}{|c|c|c|}
\hline Name of the probiotics & Beneficial effects & Reference(s) \\
\hline Bacillus spp. & Reduces the load of ammonia and nitrite & Porubcan (1991) \\
\hline Enterococcus faecium ZJ4 & Improves water quality and enhances immunity & Wang and Wang (2008) \\
\hline Lactobacillus acidophilus & Improves water quality & Dohail, Abdullah, Roshada, and Aliyu-Paiko (2009) \\
\hline Bacillus NL110, Vibrio NE1 & Reducesammonia and nitrite concentration & Mujeeb Rahiman, Yousuf, Thomas, and Hatha (2010) \\
\hline Nitrosomonas sp.,Nitrobacters sp. & $\begin{array}{l}\text { Reduces the concentration of ammonia, } \\
\text { phosphates and nitrite in culture pond }\end{array}$ & Padmavathi, Sunitha, and Veeraiah (2012) \\
\hline $\begin{array}{l}\text { Rhodopseudomonas palustris, } \\
\text { Lactobacillus plantarum, } \\
\text { Lactobacillus casei, } \\
\text { Saccharomyces cerevisiae }\end{array}$ & $\begin{array}{l}\text { Reduces nitrate load, maintain water } \mathrm{pH} \text { and } \\
\text { enhances dissolve oxygen concentration }\end{array}$ & $\begin{array}{l}\text { Melgar Valdes, Barba Macías, Alvarez-González, } \\
\text { Tovilla Hernández, and Sánchez (2013) }\end{array}$ \\
\hline Paenibacillus polymyxa & Enhances immunity and reduces pathogenic stress & Giri, Sukumaran, and Oviya (2013) \\
\hline Lactobacillus rhamnosus & Reduces pathogen load in culture tank & Talpur et al. (2013) \\
\hline Pseudomonas sp. & Enhances transcription rate of anti-microbial peptide & Ruangsri, Lokesh, Fernandes, and Kiron (2014) \\
\hline Bacillus spp & $\begin{array}{l}\text { Promotes the growth of beneficial algae and } \\
\text { reduces the growth of harmful algae }\end{array}$ & Lukwambe et al. (2015) \\
\hline Nitrosomonas sp., Nitrobacters sp. & $\begin{array}{l}\text { Reduces pathogen load in culture pond and } \\
\text { increases dissolved oxygen content }\end{array}$ & Sunitha and Krishna (2016) \\
\hline
\end{tabular}

etc. are considered to be significantly effective at present. However, Gram-negative facultative symbiotic anaerobes such as Vibrio, Pseudomonas, Plesiomonas, and Aeromonas were also reported to be potential probiotic candidates present in the gastro-intestinal tract (GIT) of fish and shellfish (Lakshmi et al., 2013; Verschuere, Rombaut, Sorgeloos, \& Verstraete, 2000). Apart from these discussed laboratory-based probiotics, various experimentally approved commercial probiotics are also available in the market which is also effective in aquaculture (Table 3).

\section{Screening of probiotics}

Although, probiotics have been used in aquaculture due to their broad spectrum biological activities but the

Table 3 Commercial probiotics for aquaculture available in the market

\begin{tabular}{|c|c|c|}
\hline Product name & Company name & Composition \\
\hline Prosol & Prosol Chemicals & $\begin{array}{l}\text { Bifidobacterium longum, Lactobacillus acidophilus, Lactobacillus rhamnosus, Lactobacillus } \\
\text { salivarius, Lactobacillus plantarum }\end{array}$ \\
\hline Progut & Lincoln Pharmaceuticals & Yeast cell wall, Mannoproteins, Betaglucans, nucleotides and peptides \\
\hline Aqualact & Biostadt India & Information is not available \\
\hline Lact-Act & Geomarine Biotechnologies & Lactobacillus sporogens \\
\hline Engest & Microtack & Bacilus subtilis, Bacillus megaterium, Bacillus licheniformis \\
\hline Grobact & Tropical Biomarine System & $\begin{array}{l}\text { Lactobacillus rhamosus, Lactobacillus acidophillus, Saccharomyces boulardii, Bacillus } \\
\text { coagulans, Streptococcus thermophilus, Bifidobacterium longum, Bifidobacterium bifidum }\end{array}$ \\
\hline Prolacto & Drug International & $\begin{array}{l}\text { Lactobacillus acidophilus, Bifidobacterium bifidum, Lactobacillus bulgaricus and fructo- } \\
\text { oligosaccharides }\end{array}$ \\
\hline ProbioDiet & Prowin Bio-Tech & Saccharomyces sp., Lactobacillus sp. and Bacillus sp. \\
\hline Hydroyeast Aquaculture & Agranco Corp & Streptococcus faecium, Lactobacillus acidophilus, Yeast, Bifidobacterium sp. and probiotics \\
\hline Biotix Plus & Matrix Biosciences & Lactobacillus sp. \\
\hline AquaStar & Biomin & Pediococcus sp., Lactobacillus sp., Enterococcus sp., Bacillus sp. \\
\hline Biocom Plus & VXL Drugs and pharmaceuticals & Information is not available \\
\hline NatuRose & Artemia International & Haematococcus pluvialis \\
\hline Enterotrophotic & $\begin{array}{l}\text { National Centre For Aquatic } \\
\text { Animal Health, India }\end{array}$ & Bacillus cereus, Arthrobacter nicotianae \\
\hline Nitro-PS+ Micro-Pro & Asian Bio Tech & Information is not available \\
\hline Pond Plus & Novozymes & Different kind of heterotrophic bacteria \\
\hline Eco-Pro & symbiosis animal feeds & Rhodopseudomonas palustris \\
\hline
\end{tabular}


selection methods of inappropriate microorganisms lead to failure of many related researches. Screening of probiotics is the first and foremost crucial step that has to be achieved through a step by step fundamental scientific research. Till date, several probiotic candidates have been reported by different research groups; however, their use is restricted in laboratory scale. A full-scale trial of these probiotics is important to commercialize these products in the market. In order to select the potential probiotics, knowledge about the mechanisms of its action is essential (Pandiyan et al., 2013). It is widely accepted that a probiotic must contain some definite features in order to aid the correct establishment of effective agents (Priyodip, Prakash, \& Balaji, 2017; Thakur, Rokana, \& Panwar, 2016). The selection criteria of probiotic include the following: (a) it should be harmless to the host; (b) it must be non-invasive, and noncarcinogenic; (c) it should reach effectively at the host's target site; (d) it should contain plasmid without antibiotic and virulence resistance genes; (e) it should be colonized for a stable time period and replicate within the host; and (f) it should actually work in host model system as opposed to in vitro findings.

However, the probiotic screening to date is concentrated on the search for active agents against a pathogen which induce the interruption in the aquatic environment. In in vitro screening for potential probiotics, most of the researchers employ identification of inhibitory or antagonistic activity (Kesarcodi-Watson, Kaspar, Lategan, \& Gibson, 2008; Sahu, Swarnakumar, Sivakumar, Thangaradjou, \& Kannan, 2008). To screen for inhibitory substances in vitro, four methods are commonly applied; the double layer method, the well diffusion method, the cross-streak method, and the disc diffusion method. The basic principle of all these methods is based on the fact that a bacterium (producer) produces an extracellular substance which is inhibitory to itself, or another bacterial strain (indicator) (Kesarcodi-Watson et al., 2008; Priyodip et al., 2017). The methods used in aquaculture include some major steps: (a) a background knowledge about the application of probiotics; (b) attainment of alleged probiotics; (c) both in vivo and in vitro assessment of their pathogenicity; and (d) a long-term practical evaluation of the treated probiotics. Recently, a number of fast and sensitive molecular tools are also used for selection and evaluation of probiotics includes ERIC-PCR and PCR-DGGE/TGGE techniques, FISH, and 16S rRNA gene sequencing ( $\mathrm{Qi}$, Zhang, Boon, \& Bossier, 2009; Wu et al., 2015) (Fig. 1).

\section{Beneficial effects and mode of action of probiotic in aquaculture}

The risk of disease enhancement in aquaculture industries fosters the probiotic research for developing sustainable aquaculture. With the increased public concern on the use of antibiotics, it is not surprising to increase a rapid growth of the probiotic for aquaculture. Food and Agricultural Organization (FAO) has now recommended the application of probiotics for the improvement of aquatic environmental quality by reducing the mortality (Subasinghe, 2005), or by increasing the resistance against putative pathogens of host (Irianto \& Austin, 2002). The beneficial effects are temporal on occasion, depending on the time of application (Verschuere et al., 2000). The effectiveness and mode of actions of many probiotics used recently in aquaculture are summarized in Table 4.

\section{Maintenance of water quality}

Probiotics help to improve water quality due to their ability to participate in the turnover of organic nutrients in aquaculture (Wang \& Wang, 2008; Wang, Zheng, Liao, Huang, \& Sun, 2007). Organic enrichment and nitrogenous wastes, including ammonium and ammonia $\left(\mathrm{NH}_{3}\right)$, are a serious concern in aquaculture, for example in pond rearing of catfish (Sahu et al., 2008). To date, the information regarding the maintenance of the balance of $\mathrm{NH}_{3} / \mathrm{NO}_{2} / \mathrm{NO}_{3}$ in pond by probiotic candidates is limited (Wang et al., 2007) (Fig. 2). There is a strong tendency to combine different photosynthetic bacteria, Bacillus, nitrifiers, and denitrifiers together; therefore, probiotics are often labeled as multifunctional and can be applied to various species under diverse culture conditions (Wang \& Wang, 2008). Apart from these, probiotics are more efficient in transforming the organic matter to $\mathrm{CO}_{2}$ (Fig. 2); therefore, it is suggested to maintain their high levels in production ponds to reduce the organic carbon load and to enhance the water quality and fish health.

\section{Augmentation of growth and survival rate}

Probiotic is also used to promote the growth of different cultivated species in aquaculture. In Javanese carp (Puntius gonionotus), Enterococcus faecalis causes significant weight gain when supplemented at $10^{7}$ and $10^{9} \mathrm{cfu} \mathrm{g}^{-1}$ diet compared to the control group of carp (Allameh et al., 2016). The microorganisms are able to colonize within the GIT due to their higher multiplication rate than the rate of expulsion after the administration over a long period of time. Probiotics are added constantly to fish cultures to maintain the health by enhancing the expression of several immunological factors, and to reduce the pathogen load to the gut mucus layer by occupying the physical space (Banerjee \& Ray, 2017). Furthermore, probiotic candidate also play a vital role in nutrient enhancement in host. Hamdan et al. (2016) have reported the enhancement of crude lipid, total protein, and body weight in Nile tilapia (Oreochromis niloticus) fed with probiotic strain of Lactobacillus sp. (Hamdan et al., 


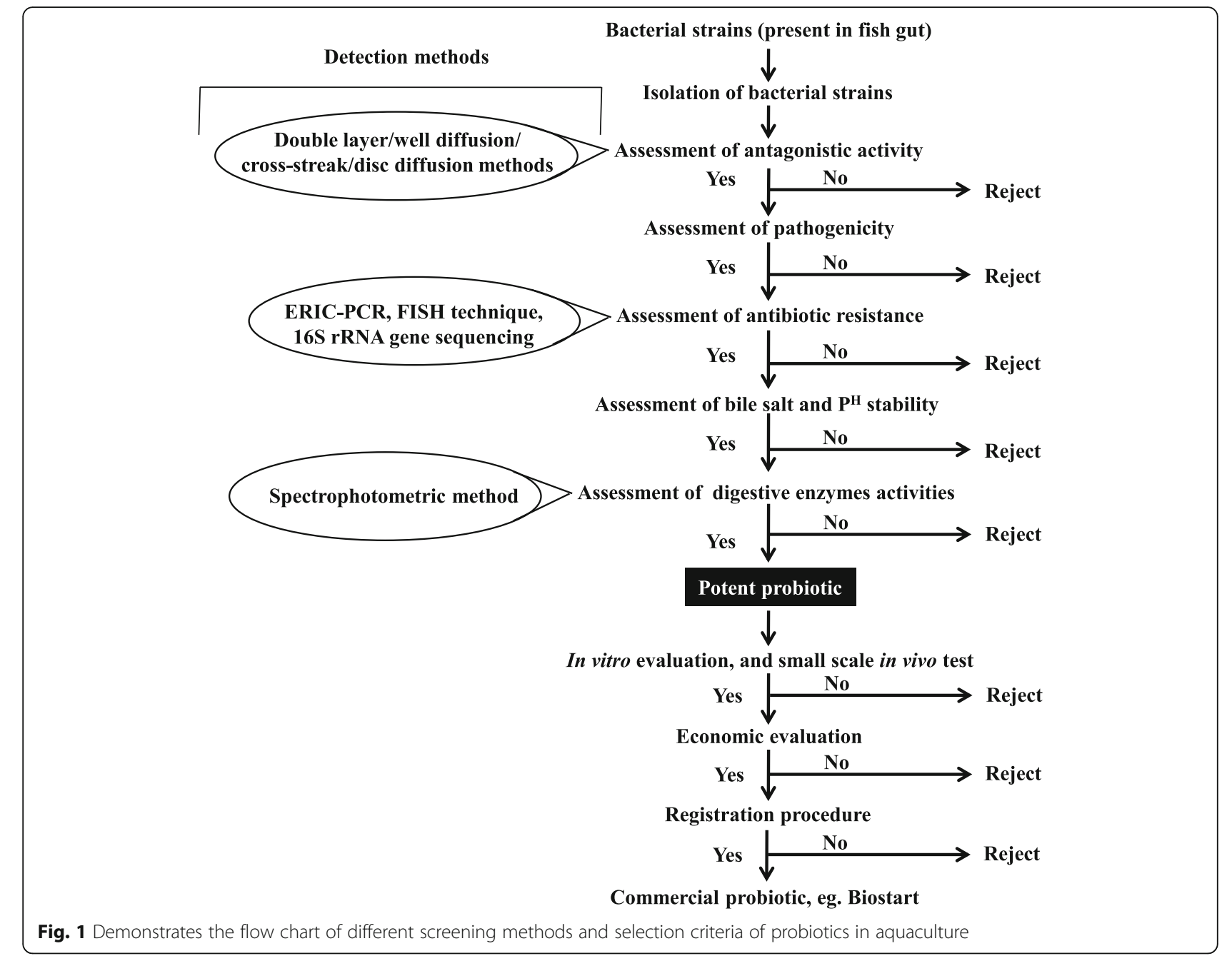

2016). This also depends on factors such as water quality, hydrobionts species, enzyme levels, and genetic resistance. Tan, Chan, Lee, and Goh (2016) have also reported that growth and survival rate increase in Xiphophorus helleri, Xiphophorus maculates, and Poecilia reticulate fed with probiotic supplemented food containing Bacillus subtilis and Streptomyces sp. (Tan et al., 2016).

\section{Improvement in nutrient utilization}

Probiotic microorganisms have beneficial effects in GIT of aquatic animals in the digestion of dietary nutrients as well as in production of energy. The most commonly used probiotic preparations in this purpose are the lactic acid bacteria (Ringø et al., 2018). It is found in large numbers in the gut of healthy animals and, in the words of Food and Drug Administration (FDA), is generally regarded as safe (GRAS status) (Giri et al., 2013). However, this increased nutrient digestibility are due to the elevated level of digestive enzymes (protease, amylase, cellulose, phytase, etc.) produced by the probiotic altered gut-associated microbial community in the host (Banerjee, Nandi, \& Ray, 2017; Burr \& Gatlin, 2005; Ghosh, Banerjee, Moon, Khan, \& Dutta, 2017). For example, few bacteria (viz. Rhodobacter sphaeroides and Bacillus sp.) participate effectively in the digestion processes by activating protease, lipase, amylase, and cellulase enzymes significantly in white shrimp (Litopenaeus vannamei) (Wang \& Wang, 2008) and in bivalves (Sahu et al., 2008). Additionally, a few recent studies have shown that probiotics may also stimulate the nutrient absorption by increasing the surface area of the host GIT, based on quantitative changes in histological measurements of the area of intestinal fold, enterochromaffin cells, and microvillus (Zhou, Buentello, \& Gatlin, 2010) (Fig. 2). It is also suggested that Lactobacillus brevis and Bacillus subtilis are capable of producing higher amount of enzyme phytase (up to $1,354,906.6 \mathrm{U} / \mathrm{mL}$ ) which helps to utilize the plant product phytate, chemically known as myo-inositol hexaphosphate (Priyodip et al., 2017). Till date, several bacterial candidates (Pseudomonas sp., Brevibacterium sp., Microbacterium sp., Agrobacterium sp., and Staphylococcus sp.) have been reported 


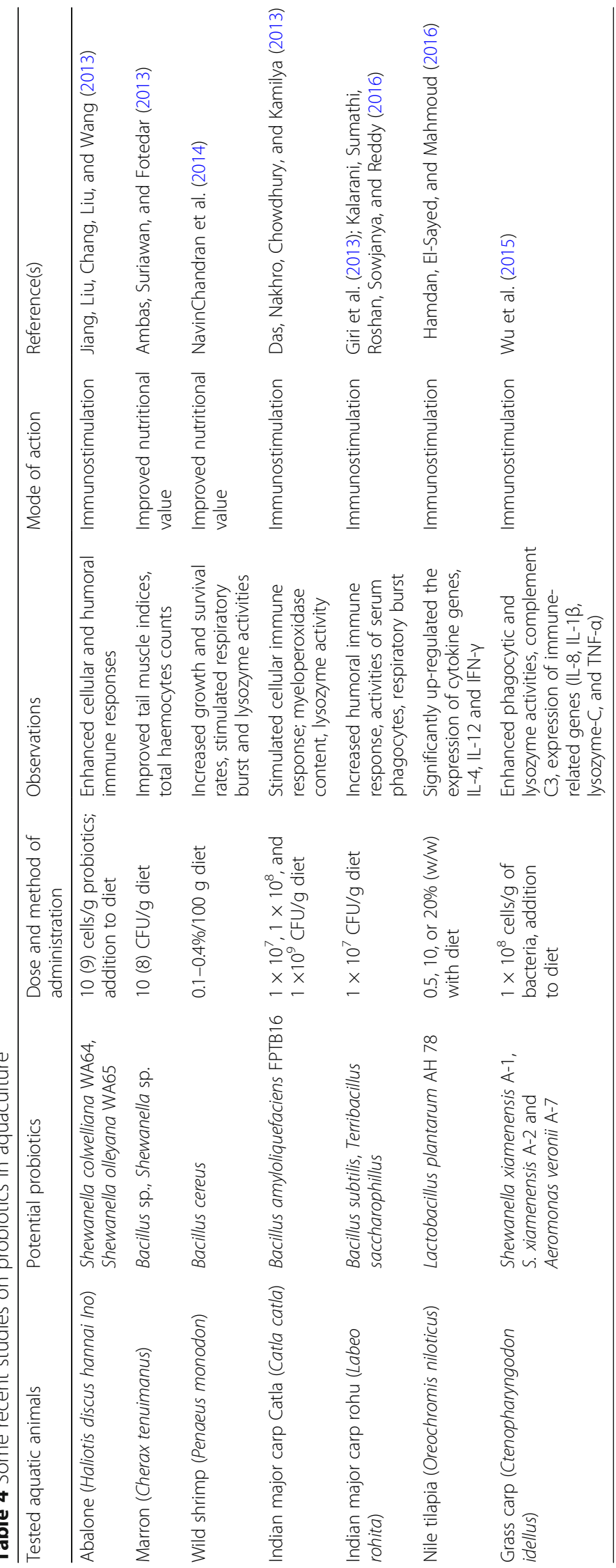




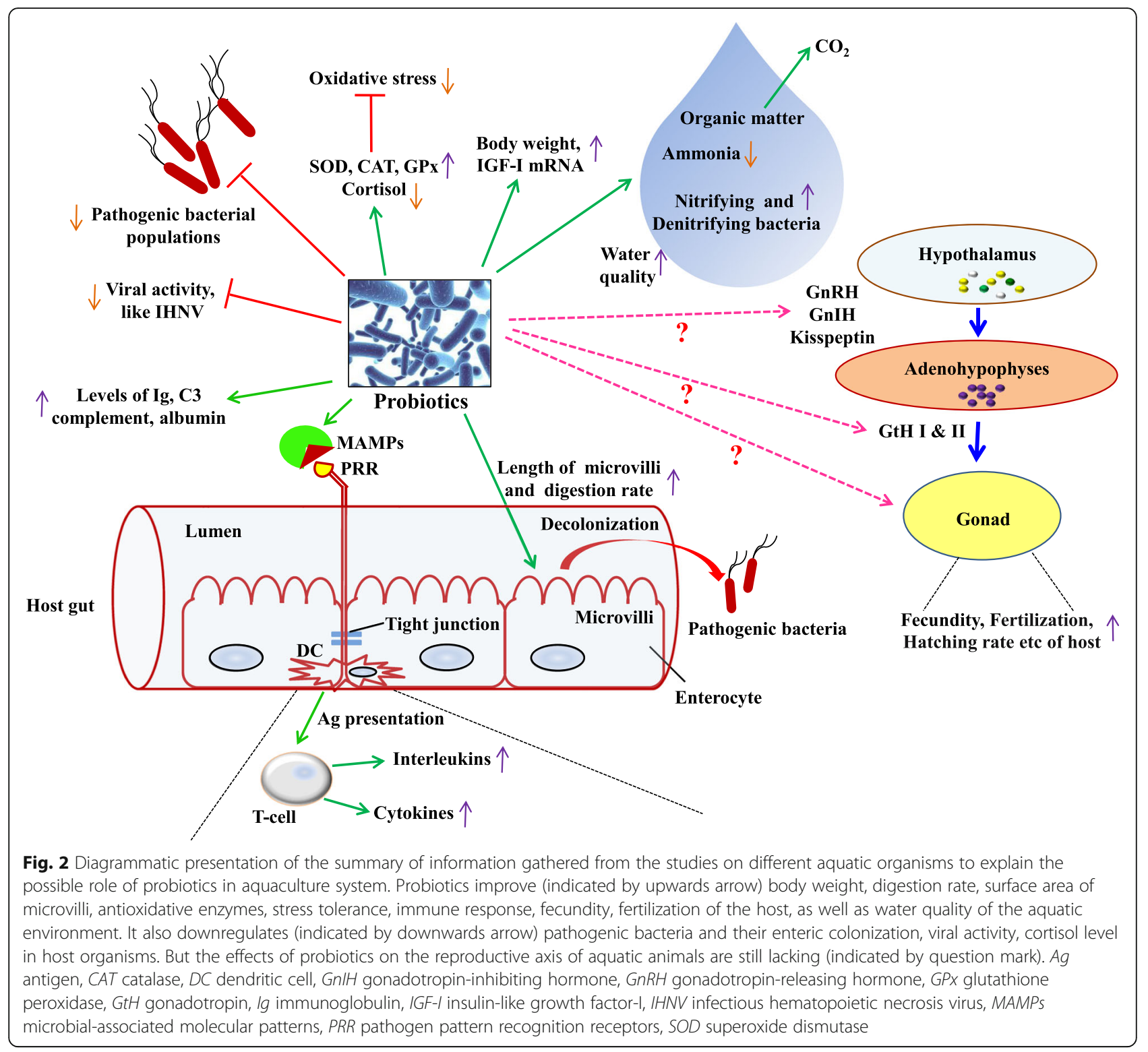

to contribute in nutritional and metabolism physiology in Arctic charr (Salvelinus alpines) (Ringø, Dimitroglou, Hoseinifar, \& Davies, 2014). Different bacterial strains in the form of probiotics also contribute significantly by modulating gut microbial population of the host organisms especially by synthesizing the fatty acids, minerals, vitamins, and essential amino acids (Nayak, 2010; Newaj-Fyzul, Al-Harbi, \& Austin, 2014).

\section{Effects on phytoplankton}

Probiotic bacteria play vital role in controlling algal growth, particularly of red tide plankton (Qi et al., 2009). Bacteria antagonistic toward algae will be undesirable in green water larval rearing technique in hatchery where unicellular algae are cultured, but will be advantageous when undesired algae species are developed in the culture pond.

\section{Bacteriostatic effects of probiotics}

Probiotic bacterial populations may release a variety of chemical substances that have a bactericidal or bacteriostatic effect on both Gram-negative and Gram-positive bacteria. These inhibitory substances belong to different origin such as proteinaceous substance (lysozyme and different kind of proteases), chemical (hydrogen peroxides), and iron-chelating compound like sideropheres (Giri et al., 2013). LAB produces a compound-bacteriocins that can alter inter-population relationships by influencing the outcome of competition for chemicals, or energy (Kesarcodi-Watson et al., 2008; Ringø et al., 2018). These inhibitory substances play an important 
role in pathogen inhibition and proliferation, and thereby reduce the pathogen load. The information about the inhibitory substances produced by probiotic bacteria are given in Table 5 .

\section{Stimulation of decolonization of pathogenic bacteria}

One possible mechanism for preventing colonization by pathogens is physical competition for attachment sites on the gut mucosal layer in host. It is known that the ability to adhere to mucus and wall surfaces is necessary for bacteria to become established in fish intestines (Cruz, Ibáñez, Hermosillo, \& Saad, 2012; Roeselers et al., 2011). Since bacterial adhesion to tissue surface is important during the initial stages of pathogenic infection, competition for adhesion receptors with pathogens might be the first probiotic effect (Chabrillón, Arijo, Díaz-Rosales, Balebonz, \& Moriñigo, 2006). In general, probiotic microorganisms possess mucus binding proteins which help in the acceleration of the binding process. In an investigation, Mackenzie et al. (2010) have reported the differential expression pattern of a key receptor mub in different strains of Lactobacillus, and have compared their binding efficacy in the gut mucosa (Mackenzie et al., 2010).

\section{Augmentation in the immune system}

Probiotics play the beneficial role as immunostimulatory to assist in the protection of aquatic cultured species by reducing the impact of diseases and entrance of pathogens (Dawood \& Koshio, 2016; Hai, 2015). Thus, its use as an immunostimulants is very practical approach to improve the success of the aquaculture. Many authors have confirmed the use of probiotics to elevate immune response, disease resistance, and reduce malformations in carp species (Wu et al., 2015). The possible mechanism of its action is cellular as well as humoral immune responses, and expression of IL-1b, TNF $\alpha$, and
lysozyme-C are increased when fish are fed with Aeromonas veronii, Vibrio lentus, and Flavobacterium sasangense enriched diet (Dawood \& Koshio, 2016). Myeloperoxidase, lysozyme, complement component C3, albumin and immunoglobulin levels, respiratory burst activity, and phagocytic activity by blood leucocytes are improved in several fish species (Chi et al., 2014; Giri et al., 2013). An experimental report have supported that probiotics supplemented at $10 \mathrm{CFU} / \mathrm{g}$ diet for 2 weeks act as an immunomodulator by binding its MAMPs (microbial associated molecular patterns) to pathogen pattern recognition receptors (PRRs) on immunogenic cells like dendritic cells, macrophages, which trigger intracellular signaling cascade, resulting in the release of specific cytokines and interleukins by the activated $\mathrm{T}$ cells to exert anti-viral, pro- or anti-inflammatory exercise effects (Akhter, Wu, Memon, \& Mohsin, 2015; Balcázar et al., 2006) (Fig. 2). Unfortunately, the specific role of probiotic supplementation on the immunological parameter expression is still not clearly understood.

\section{Effects on viral pathogens}

Though, data indicate that virus inactivation can occur by some extracts from different probiotic bacterial strains in aquaculture but the exact mechanism by which it exerts its action is not known. It is well established that probiotic candidates like Pseudomonas sp. and Vibrios sp. are very effective against 'infectious hematopoietic necrosis virus' (IHNV) (Sahu et al., 2008). Furthermore, Paralychthys olivaceus fed with Sporolac (Lactobacillus sp.) supplemented food develop resistance against lymphocystis disease virus (LCDV) (Harikrishnan, Balasundaram, \& Heo, 2010). Similar experiments have also proved the enhanced virus resistance power in grouper fish fed with probiotic strain of Bacillus subtilis E20 (Liu, Chiu, Wang, \& Cheng, 2012).

Table 5 Production of inhibitory substances by probiotic candidates

\begin{tabular}{|c|c|c|c|}
\hline Probiotic candidates & Inhibitory substances & Inhibitory pathogens & Reference(s) \\
\hline Vibrio anguillarumVL4335 & Siderophore & Vibrio ordalii & Pybus, Loutit, Lamont, and Tagg (1994) \\
\hline Vibrio sp. & Siderophore & Vibrio splendidus & Gatesoupe, (1997) \\
\hline Pseudomonas fluorescence $\mathrm{AH} 2$ & Siderophore & Vibrio anguillarum & $\begin{array}{l}\text { Gram, Melchiorsen, Spanggaard, Huber, } \\
\text { and Nielsen (1999) }\end{array}$ \\
\hline $\begin{array}{l}\text { Photobacterium leiognathi, Vibrio } \\
\text { scophthalmi and Enterovibri norvegicus }\end{array}$ & Siderophore & N/D & Sugita, Mizuki, and Itoi (2012) \\
\hline Lactobacillus murinus AU06 & Bacteriocin & Vibrio sp., Micrococcus & $\begin{array}{l}\text { Elayaraja, Annamalai, Mayavu, and } \\
\text { Balasubramanian (2014) }\end{array}$ \\
\hline Pediococcus acidilactici L-14 & Pediocin PA-1 & N/D & Araújo et al. (2016) \\
\hline Bacillus subtilis LR1 & Bacteriocin & $\begin{array}{l}\text { Aeromonas hydrophila, Aeromonas } \\
\text { salmonicida, Bacillus mycoides and } \\
\text { Pseudomonas fluorescens }\end{array}$ & Banerjee et al. (2017) \\
\hline Strains H4 (not identified) & Bacteriocin & Pseudomonas stutzeri & Feliatra et al. (2018) \\
\hline
\end{tabular}




\section{Effects on reproduction}

The use of probiotics on disease resistance ability is well documented, but research on the effects and action mechanism of probiotics on the reproductive performance of aquatic animals are lacking (Fig. 2). Very few studies have attempted to demonstrate the role of probiotic supplementation on reproductive performance in aquaculture (Abasali \& Mohammad, 2011; Ghosh, Sinha, \& Sahu, 2007), using various strains like B. subtilis, Lactobacillus acidophilus, Lactobacillus casei. It is well documented that probiotics influence reproduction in different factors like fertilization, gonadosomatic index, fecundity, and production of fry from the females (Abasali \& Mohammad, 2011). Recent study also reported that probiotics increase the daily numbers of ovulated eggs compared to control levels with higher hatching rate and faster embryonic development in zebrafish (Gioacchini et al., 2013). However, rigorous experiments still need to be established for the utilization of probiotics to increase the production rate of aquatic animals.

\section{Other functions}

Very few recent investigations also highlight the effects of probiotics on some major physiological processes in aquatic organisms. In European seabass, it helps to increase the body weight by stimulating the mRNA transcription of insulin-like growth factor (IGF)-I (Carnevali, Sun, Merrifield, Zhou, \& Picchietti, 2014). Additionally, it is now profoundly accepted that probiotics reduce the concentration of the stress hormone cortisol and activate the expression of antioxidative enzymes (superoxide dismutase, catalase, and glutathione peroxidase) to increase the stress tolerance (Zolotukhin, Prazdnova, \& Chistyakov, 2018) (Fig. 2), which are essential for better reproductive performance in aquatic organisms (Hasan, Moniruzzaman, \& Maitra, 2014; Hasan, Pal, \& Maitra, 2020).

The mode of probiotic application can be in several ways: (i) addition to the artificial diet and culture water, and (ii) bathing and addition via live food. Furthermore, understanding the mode of action along with proper application methods may be the key for probiotics use in aquaculture. Although the exact mode of action is yet to be revealed, it often exert host as well as strain-specific differences in their activities. However, the use of probiotics is gaining potential scientific and commercial interest in aquaculture at global basis (Banerjee \& Ray, 2017; Carnevali et al., 2014; Hoseinifar, Ringø, Masouleh, \& Esteban, 2016).

\section{Probiotics and different types of food in aquaculture}

The use of balanced probiotic containing feed is a common practice in commercial aquaculture sectors which provides several beneficiary effects to farmer and consumers in term of improved growth performance, flesh quality, production rate, fish immunity, protein quantity, carcass quality, intestinal health, and reduced malformations (Hai, 2015; Ige, 2013). However, a huge number of farmers from developing and low-income countries still rely on natural feeds (usually phytoplankton and zooplankton) for fish farming to reduce the production cost, but it reduces the production rate, flesh quality, and enhances mortality, and thus ultimately affects the income. Several researchers have proved that probiotic feeding in fish from their first stage of life (larvae) is profitable due to diseases load is low in later stage (Table 6), but the delivery of probiotics during early stage is quite difficult. The protection of hatchling or larvae is the most challenging issue in aquaculture. So, the manipulation of

Table 6 Interaction between probiotics and different types of food in fish farming

\begin{tabular}{|c|c|c|c|}
\hline Fish species larvae & Probiotic feed & Beneficiary effects & References \\
\hline Scophthalmus maximus & $\begin{array}{l}\text { Lactic acid bacteria enriched Brachionus } \\
\text { plicatilis }\end{array}$ & Resistant against wide range of Vibrio sp. & Gatesoupe (1994) \\
\hline Scophthalmus maximus & $\begin{array}{l}\text { Probiotic bacteria enriched Brachionus } \\
\text { plicatilis }\end{array}$ & $\begin{array}{l}\text { Promoted colonization on the gut and } \\
\text { enhanced survival rate }\end{array}$ & $\begin{array}{l}\text { Makridis, Fjellheim, Skjermo, } \\
\text { and Vadstein (2000) }\end{array}$ \\
\hline Sparus aurota & $\begin{array}{l}\text { Lactobacillus fructivorans and Lactobacillus } \\
\text { plantarum enriched dry feed or live feed } \\
\text { (Brachionus plicatilis and Artemia salina) }\end{array}$ & $\begin{array}{l}\text { Enhanced colonization on the gut epithelial } \\
\text { surface and significantly reduced the } \\
\text { mortality rate during larval rearing and } \\
\text { fry culture }\end{array}$ & Carnevali et al. (2004) \\
\hline Gadus morhua & $\begin{array}{l}\text { Life feed enriched probiotic bacteria } \\
\text { Phaeobacter gallaeciensis }\end{array}$ & $\begin{array}{l}\text { Reduced the pathogenic load during } \\
\text { larviculture }\end{array}$ & D'Alvise et al. (2012) \\
\hline Seriola lalandi & $\begin{array}{l}\text { Live feed (B. rotundiformis and B. plicatilis) } \\
\text { and Artemia sp.) enriched with } \\
\text { Pseudoalteromonas sp. }\end{array}$ & Enhanced survival rate of the larvae. & $\begin{array}{l}\text { Sayes, Leyton, and Riquelme } \\
\text { (2018) }\end{array}$ \\
\hline Scophthalmus maximus & $\begin{array}{l}\text { Bacillus amyloliquefaciens enriched } \\
\text { Branchionus plicatils and Artemia sinica }\end{array}$ & $\begin{array}{l}\text { It improves the microbial community in } \\
\text { live feed and ultimately confers the } \\
\text { beneficial effects to larvae }\end{array}$ & Jiang et al. (2018) \\
\hline Centropomus undecimalis & $\begin{array}{l}\text { Bacillus licheniformis and Bacillus } \\
\text { amyloliquefaciens enriched feed }\end{array}$ & $\begin{array}{l}\text { Improved water quality, fish health and } \\
\text { rearing tank environment }\end{array}$ & $\begin{array}{l}\text { Tarnecki, Wafapoor, Phillips, } \\
\text { and Rhody (2019) }\end{array}$ \\
\hline
\end{tabular}


microbiota by inoculating probiotic strain and their uses is a promising alternative. However, in later stage, probiotic-enriched formulated artificial balanced diet is good for fish health and the application of it is very easy. Moreover, farmers have to be careful of three main constraints (Vadstein et al., 2018; Vine, Leukes, \& Kaiser, 2006) viz., (a) leaching of feed which reduces the availability of probiotic to the host. Thus, dose standardization and regular monitoring is required. (b) Probiotic candidate confers beneficial effects to the host only when it is active or live under different appropriate environmental conditions, so farmers have to be concern about these facts. (c) Nature of various ponds differ depending on the physicochemical parameters and natural feeds (zooplankton and phytoplankton). So, application, types, and dose of probiotics will be varied accordingly.

\section{Probiotics and fish gut microbial community}

Gut environment provides a favorable niche for indigenous microorganism by providing space, attachment sites, and nutrition. Balanced microbial communities are very important for maintaining gut health (Banerjee \& Ray, 2017; Giatsis et al., 2016). During disease condition, the natural microbial communities in the gut are disrupted, which creates several health-related problems. Fish lives in such a condition which is surrounded by a huge population of pathogenic bacteria, fungi, and deadly virus (Egerton, Culloty, Whooley, Stanton, \& Ross, 2018).
Restoration of gut microbial communities through dietary probiotic supplementation is an effective method to improve fish health (Han et al., 2015). However, selection of probiotics varies greatly from one fish species to another to properly maintain the good to bad ratio of bacteria in the gut mucosal surface. Till date several bacterial candidates have been tested for probiotic potential; however, few candidates of Bacillus sp., Micrococcus sp., Enterococcus sp., Phaeobacter sp., Shewanella sp., lactic acid bacteria, and Pseudomonas sp. have gained popularity in manipulating gut flora in fish (Lobo et al., 2014; Merrifield et al., 2010a, b). In an investigation, Asaduzzaman and coworkers have reported the beneficiary effects of three probiotics (Shewanella sp. AFG21, Bacillus sp. AHG22, and Alcaligenes sp. AFG22) in Tor tambroides which are able to shift the microbial composition toward good bacterial populations (Asaduzzaman et al., 2018). Several researchers reported that probiotic significantly induced many fold gut microbiota to produce several metabolites including volatile short-chain fatty acids (VSCFs), which play a vital role in maintaining gut health in fish (Fig. 3) (Allameh, Ringø, Yusoff, Daud, \& Ideris, 2017; Asaduzzaman et al., 2018; Burr \& Gatlin, 2005). Researchers also reported that probiotic modulation of gut microbiota is not restricted to fish age and maturation, as probiotics confer beneficial effects to all age group ranging from larvae to adult (Merrifield \& Carnevali, 2014). A previous study reported that probiotic supplemented diet in rainbow

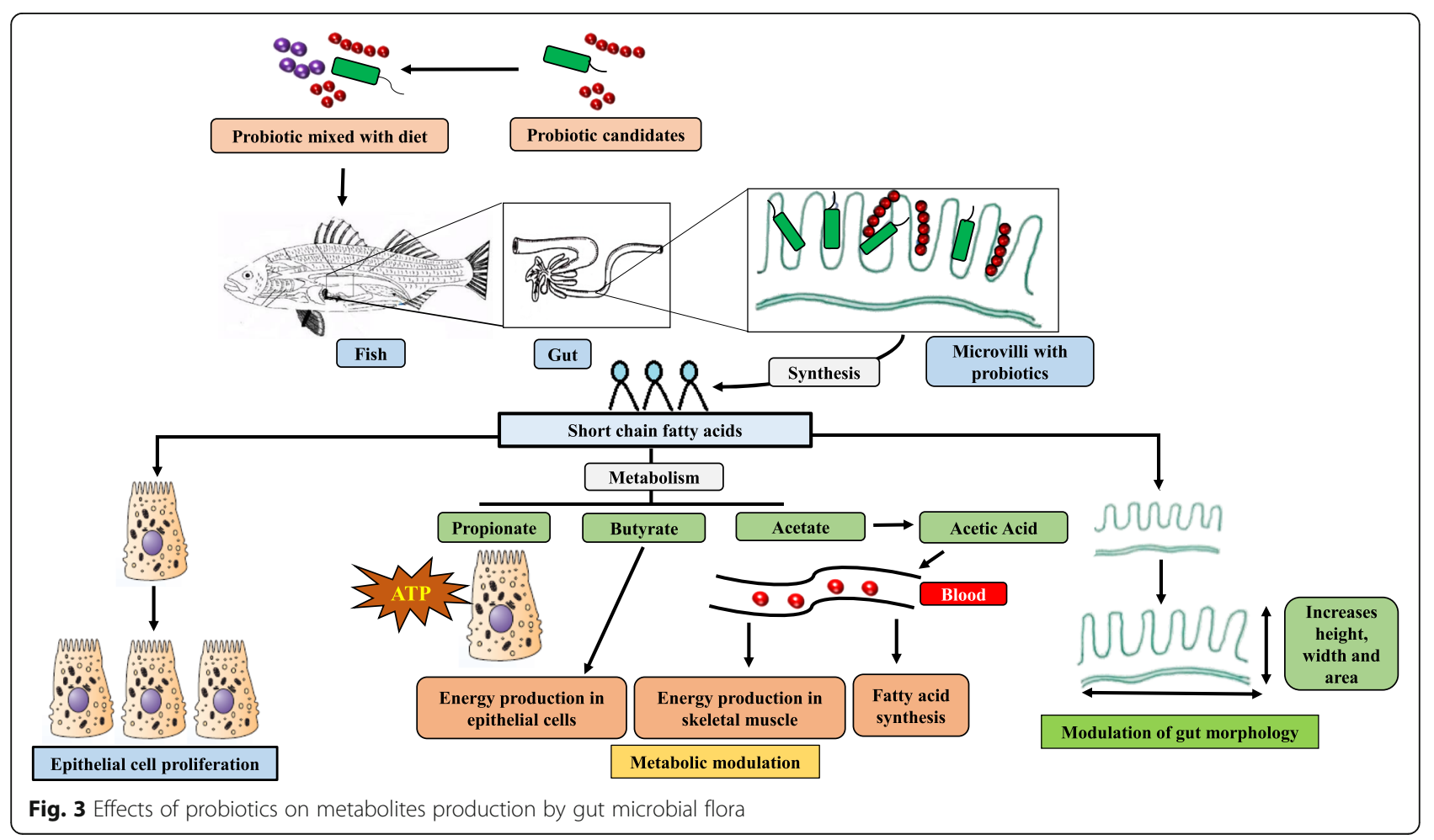


trout was very effective to enhance the population of beneficial bacterium Bacillus subtilis (Newaj-Fyzul et al., 2007). They also reported that colonization of $B$. subtilis on the gut epithelial surface conferred protection (boost immunity, reduced oxidative stress, increased serum lysozyme concentration, and enhance phagocytic activity of specialized cell) against pathogenic strain of Aeromonas sp. The finding of Newaj-Fyzul and co-workers (Newaj-Fyzul et al., 2007) was further supported by the study conducted by Bagheri, Hedayati, Yavari, Alizade, and Farzanfar (2008), who used commercial probiotic product (Bioplus) containing a mixture of $B$. subtilis and Bacillus licheniformis. In the same direction, an investigation conducted in four fish species (Poecilia sphenops, Xiphophorus maculates, Poecilia reticulate, and Xiphophorus helleri) fed with $B$. subtilis containing diet and reported the population enhancement of B. subtilis on the intestinal mucosal surface (Ghosh, Sinha, \& Sahu, 2008). Recently, the effects of two probiotic strains Bacillus subtilis and Rhodococcus sp. have evaluated on gut microbiota of Oreochromis niloticus (Martínez Kathia et al., 2018). The results of their study clearly indicated a significant shifting of gut microbial community (increasing percentage of proteobacteria and bacteroidetes) in probiotic fed fish compared to control. Furthermore, study also reported that bacteria belongs to phyla proteobacteria are important members as they are involved in mineralization of organic compounds and nutrient recycling process in fish (Cardona et al., 2016). However, the gut microbiota restoration capability of two probiotics also tested in diseased black molly (Poecilia sphenops) treated with antibiotics (Schmidt, Gomez-Chiarri, Roy, Smith, \& Amaral-Zettler, 2017). Results of their study indicated that both the probiotic candidates (Phaeobacter inhibens S4Sm and Bacillus pumilus RI06-95Sm) were able to restore the microbial community back to the normal. Among several probiotic strains, lactobacillus groups as probiotics in aquaculture have been studied extensively. It is well established that lactobacilli has high colonization property and thus retain for a longer time on the gut epithelial surface, and confer greater beneficial effects to host and gut microbiota (Merrifield \& Carnevali, 2014). Researches on germfree fish model indicated that probiotic along with environmental factors have high impact on gut microbiota modulation in term of antibody production, stress release, and resistance colonization (Kelly \& Salinas, 2017). The microbial manipulating property of probiotic on gut mucosal surface depends on several external/environmental (water quality, temperature and $\mathrm{pH}$ ) and internal (fish age, binding strength of the probiotic, duration of probiotic supplement diet, delivery system, etc.) factors. Alteration in any of these factors may hamper the probiotic efficiency. The cross talk between host and microbe on the gut epithelial surface is a complex phenomenon and is responsible to maintain a healthy environment. Restoration of gut microbiota in patient using fecal microbial therapy (microbiota collected from healthy individual) to solve several diseases is common practice in human (Aas, Gessert, \& Bakken, 2003). The probiotic research in mammal including human is at peak level; however, such depth of research is still lacking in the case of aquaculture.

\section{Probiotics and mucosal immunity}

Apart from systemic immunity, fish possess a welldefined mucosal immunity which is very important for protection and survival. Till date, the mucosal immunity in fish has been studied mostly in teleost fish (Lazado \& Caipang, 2014). Mucosa-associated lymphoid tissues (MALT) in teleosts can be divided into three broad categories: skin-associated lymphoid tissue (SALT), gutassociated lymphoid tissue (GALT), and gill-associated lymphoid tissue (GIALT). However, lymphoid tissue [nasopharynx-associated lymphoid tissue (NALT)] has recently been discovered by Salinas (2015). Immunomodulation by probiotic bacteria is a vital process which confers strength to fish for combating with surrounding pathogen in the water, as well as inside the body. The mucosal secretion in fish contain a wide spectrum of anti-microbial peptides (AMPs) such as AJN-10 (Liang, Guan, Huang, \& Xu, 2011), Gaduscidin-1 and -2 (Browne, Feng, Booth, \& Rise, 2011), Piscidin 3 (Dezfuli, Giari, Lui, Lorenzoni, \& Noga, 2011), and YFGAP (Seo, Lee, Go, Park, \& Park, 2012), which have direct role in pathogen inhibition (Fuochi et al., 2017; Gallo \& Nakatsuji, 2011; Gomez, Sunyer, \& Salinas, 2013). Skin mucus layer act as a first defence barrier in fish, as it is in direct contact with water. Among the lymphoid tissues, GALT is the most important one and interestingly in fish it lacks Peyer's patches like mammal. However, GALT contains the other important components (plasma cells, macrophages, lymphocytes, etc.), which are necessary for defense (Lazado \& Caipang, 2014). It was reported that probiotic modulate the mucosal immunity in fish by increasing the population (10-30\%) of granulocytes and lymphocytes cells which is related to cell mediated mucosal defence (Lazado \& Caipang, 2014). Furthermore, an investigation on GALT of seabream (Sparus aurata) also reported that oral administration of a mixture of probiotic strains (Lactobacillus plantarum and Lactobaccillus fructivorans) enhanced the production of antibody and $\mathrm{G7}^{+}$ granulocytes cells (Picchietti et al., 2007). In general, plasma cells of fish produce three types of antibodies: IgM, IgD, and IgZ. The action of IgT/IgZ is thought to be associated with the gut mucosal immunity in fish (Salinas, Zhang, \& Oriol Sunyer, 2011). Whereas, IgM is a general immunoglobulin responsible for combating invaded pathogen and the level of this antibody is elevated in the gut mucus in fish fed with 
probiotic supplemented diet (Salinas et al., 2008). Probiotic administration also enhanced the population of IgM producing B cell in gut lamina propria in juvenile fish (Abelli, Randelli, Carnevali, \& Picchietti, 2009). Similarly, effect of probiotic on gut integrity and gut mucosal immunity in rainbow trout (Oncorhynchus mykiss) fingerling have also tested (Gisbert, Castillo, Skalli, Andree, \& Badiola, 2013). Result of various studies also confirmed that Bacillus cereus confers significant beneficial effects on gut by increasing villi height (average $14.5 \%$ ), villi area (average 28.6\%), villi weight, as well as by enhancing the leucocytes infiltration and goblet cell number $(1.63 \pm 0.03$ in respect to control $1.22 \pm 0.05$ per $100 \mu \mathrm{m}$ of intestinal epithelium) (Asaduzzaman et al., 2018; Gisbert et al., 2013). Nowadays, the research on fish mucosal immunity gain a huge popularity and several researchers are involved in this field (Table 7). Immunization/vaccination is an effective method in disease resistance, but its use is still limited in aquaculture sectors (Liu et al., 2019). It is believed that vaccination of fish to boost the gut mucosal immunity is more effective rather than systemic immunity. Though, probiotics are very effective in protection against a wide range of pathogens, but the use of mucosal vaccines is the first choice as it lengthens the protection period (Munang'andu, Mutoloki, \& Evensen, 2015).

\section{Conclusion and future perspectives}

The current researches improvise and optimize the utilization of probiotics in aquaculture industry. Notably, the future application also looks bright due to the everincreasing demand of probiotics for aquacultured animals. Further investigations will demonstrate the techniques to screen host specific probiotic strains from aquaculture rearing system to manage significantly its quality and functional properties. Furthermore, research should also focus on studying the effects and mechanism of action of probiotics on the reproductive performance and gonadal development of aquatic organisms in an industrial scale hatchery system. Probiotic bacteria confer a broad spectrum of beneficiary effects to host, but still there are certain limitations. For example, antimicrobial compounds or bacteriocins produced by probiotic candidates against pathogenic bacteria are not species specific. Thus, strain improvement is necessary to enhance the efficiency of probiotic bacteria. There are several molecular biology techniques such as recombinant technology, mutagenesis, etc. that are available to improve the genetic makeup of the probiotic strain. However, application of these techniques is limited to probiotic candidates used for aquaculture. Future investigation must be done to solve these serious issues and to prepare effective probiotics.

Table 7 Effects of probiotics on fish mucosal immunity

\begin{tabular}{|c|c|c|c|}
\hline Probiotic candidates/products & Fish species & Effects on mucosal immunity/morphology & References \\
\hline $\begin{array}{l}\text { Lactococcus lactis, Lactobacillus } \\
\text { sakei, and Leuconostocmesenteroides }\end{array}$ & Oncorhynchus mykiss & $\begin{array}{l}\text { Enhance phagocytic activity of gut mucosal } \\
\text { leucocytes }\end{array}$ & Balcázar et al. (2006) \\
\hline Pediococcusacidilactici & Oncorhynchus mykiss & $\begin{array}{l}\text { Increase surface area for absorbtion by increasing } \\
\text { villi length }\end{array}$ & Merrifield et al. $(2010 a, b)$ \\
\hline GP21 and GP12 & Gadus morhua & $\begin{array}{l}\text { Lower down caspase- } 3 \text { and lactate dehydrogenase } \\
\text { activity of the pathogen infected gut epithelial cells }\end{array}$ & $\begin{array}{l}\text { Lazado, Caipang, Brinchmann, } \\
\text { and Kiron (2011) }\end{array}$ \\
\hline Bacillus subtilis FPTB13 and chitin & Catla catla & $\begin{array}{l}\text { Foster the production of skin mucosal lysozyme, } \\
\text { alkaline phosphatase, myeloperoxidase content } \\
\text { and total protein } \\
\text { content }\end{array}$ & Sangma \& Kamilya, (2015) \\
\hline Shewanellaputrefaciens & Sparus aurata & $\begin{array}{l}\text { Enhance the activity of skin mucosal lysozyme } \\
\text { and complement C } 3 \text {. Enhance the expression } \\
\text { of nonspecific cytotoxic cell receptor protein } \\
1 \text { and natural killer cell enhancing factor. }\end{array}$ & $\begin{array}{l}\text { Cordero, Morcillo, Cuesta, } \\
\text { Brinchmann, and Esteban (2016) }\end{array}$ \\
\hline $\begin{array}{l}\text { Bacillus coagulans and } \\
\text { Lactobacillusplantarum }\end{array}$ & Danio rerio & $\begin{array}{l}\text { Enhance intraepithelial lymphocytes cell } \\
\text { population. Up-regulation of TNF-a and IL-10 }\end{array}$ & Wang, Ren, Fu, and Su (2016) \\
\hline $\begin{array}{l}\text { galactooligosaccharide (prebiotic) } \\
\text { and Pediococcusacidilactici }\end{array}$ & Cyprinus carpio & $\begin{array}{l}\text { Enhance immunoglobulin concentration in } \\
\text { skin mucus }\end{array}$ & $\begin{array}{l}\text { Modanloo, Soltanian, Akhlaghi, } \\
\text { and Hoseinifar (2017) }\end{array}$ \\
\hline $\begin{array}{l}\text { Vitace }^{\circledR} \text { and PrimaLac } \\
\text { Lactobacillus plantarum and }^{\oplus} \\
\text { Cordyceps militaris spent } \\
\text { mushroom }\end{array}$ & $\begin{array}{l}\text { Rutiluskutum } \\
\text { Oreochromis niloticus }\end{array}$ & $\begin{array}{l}\text { Modulate mucosal immunity and enhance } \\
\text { digestive enzyme activity Enhance the activity } \\
\text { of skin mucus lysozyme and peroxidase }\end{array}$ & $\begin{array}{l}\text { Mirghaed et al. (2018) } \\
\text { Van Doan, Hoseinifar, Dawood, } \\
\text { Chitmanat, and Tayyamath (2017) }\end{array}$ \\
\hline $\begin{array}{l}\text { Bacillus amyloliquefaciens (GB-9) } \\
\text { and Yarrowialipolytica lipase2 (YLL2) }\end{array}$ & $\begin{array}{l}\text { Hybrid sturgeon } \\
\text { (Acipenserschrenkii } \times \\
\text { Acipenser baerii) }\end{array}$ & $\begin{array}{l}\text { Enhance mucus lysozyme activity and leukocytes } \\
\text { phagocytic activity }\end{array}$ & Fei et al. (2018) \\
\hline $\begin{array}{l}\text { Lactobacillus casei and } \\
\text { Agaricus bisporus }\end{array}$ & Danio rerio & $\begin{array}{l}\text { Upregulated the expression of mucosal immune } \\
\text { genes (TNF-a, LYZ, and IL1B) and anti-oxidant } \\
\text { genes like SOD, CAT }\end{array}$ & $\begin{array}{l}\text { Safari, Hoseinifar, Dadar, and } \\
\text { Khalili (2018) }\end{array}$ \\
\hline
\end{tabular}




\section{Abbreviations}

AMPs: Anti-microbial peptides; CFU: Colony forming unit; FAO: Food and Agriculture Organization; FDA: Food and Drug Administration; GALT: Gutassociated lymphoid tissue; GIALT: Gill-associated lymphoid tissue; GIT: Gastro-intestinal tract; IFN: Interferon; IGF: Insulin-like growth factor; IHNV: Infectious hematopoietic necrosis virus; IL: Interleukin; LAB: Lactic acid bacteria; LCDV: Lymphocystis disease virus; MALT: Mucosa-associated lymphoid tissues; MAMPs: Microbial-associated molecular patterns; NALT: Nasopharynx-associated lymphoid tissue; PCR: Polymerase chain reaction; PRR: Pathogen pattern recognition receptors; SALT: Skin-associated lymphoid tissue; TNFa: Tumour necrosis factor alpha; VSCFs: Volatile shortchain fatty acids

\section{Acknowledgements}

We are very much thankful to Department of Zoology, Sidho-Kanho-Birsha University, Purulia, India for providing necessary supports. The authors are thankful to Mr. Akash Acharyya for his academic support.

\section{Authors' contributions}

Both the authors contributed equally in preparation of the manuscript.

\section{Funding}

This work was funded by University Grants Commission (UGC) [F.30- 448/ 2018(BSR)] to KNH and DBT-Boost Programme, Govt of West Bengal, India.

\section{Availability of data and materials}

Data and relevant information were obtained from NCBI-PUBMED central, Scopus, MEDLINE and Google scholar.

\section{Ethics approval and consent to participate}

Not applicable.

\section{Consent for publication}

Not applicable.

\section{Competing interests}

The authors declare that they have no competing interest.

\section{Author details}

'Department of Zoology, Sidho-Kanho-Birsha University, Purulia 723104, India. ${ }^{2}$ Department of Biochemistry, University of Calcutta, Kolkata 700019, India.

Received: 2 December 2019 Accepted: 10 August 2020

Published online: 27 August 2020

\section{References}

Aas, J., Gessert, C. E., \& Bakken, J. S. (2003). Recurrent Clostridium difficile colitis: case series involving 18 patients treated with donor stool administered via a nasogastric tube. Clinical Infectious Diseases, 36(5), 580-585.

Abareethan, M., \& Amsath, A. (2015). Characterization and evaluation of probiotic fish feed. International Journal of Pure and Applied Zoology, 3(2), 148-153.

Abasali, H., \& Mohammad, S. (2011). Dietary prebiotic immunogen supplementation in reproductive performance of platy (Xiphophorus maculatus). Veterinary Research, 4, 66-70.

Abelli, L., Randelli, E., Carnevali, O., \& Picchietti, S. (2009). Stimulation of gut immune system by early administration of probiotic strains in Dicentrarchus labrax and Sparus aurata. Annals of the New York Academy of Sciences, 1163(1), 340-342

Akhter, N., Wu, B., Memon, A. M., \& Mohsin, M. (2015). Probiotics and prebiotics associated with aquaculture. A review. Fish and Shellfish Immunology, 45(2), 733-741.

Allameh, S. K., Ringø, E., Yusoff, F. M., Daud, H. M. A., \& Ideris, A. (2017). Dietary supplementation of Enterococcus faecalis on digestive enzyme activities, short chain fatty acid production, immune system response and disease resistance of Javanese carp (Puntius gonionotus Bleeker 1850). Aquaculture Nutrition, 23(2), 331-338.

Allameh, S. K., Yusoff, F. M., Ringø, E., Daud, H. M., Saad, C. R., \& Ideris, A. (2016). Effects of dietary mono-and multiprobiotic strains on growth performance, gut bacteria and body composition of Javanese carp (Puntius gonionotus, Bleeker 1850). Aquaculture Nutrition, 22(2), 367-373.
Ambas, l., Suriawan, A., \& Fotedar, R. (2013). Immunological responses of customised probiotics-fed marron, Cherax tenuimanus, (Smith 1912) when challenged with Vibrio mimicus. Fish and Shellfish Immunology, 35(2), 262-270.

Araújo, C., Muñoz-Atienza, E., Poeta, P., Igrejas, G., Hernández, P. E., Herranz, C., \& Cintas, L. M. (2016). Characterization of Pediococcus acidilactici strains isolated from rainbow trout (Oncorhynchus mykiss) feed and larvae: safety, DNA fingerprinting, and bacteriocinogenicity. Diseases of Aquatic Organisms, $119(2), 129-143$.

Asaduzzaman, M., Peiiehata, S., Akter, S., Kader, M. A., Ghosh, S. K., Nurul Khan, A., \& Abol-Munaf, A. B. (2018). Effects of host gut-derived probiotic bacteria on gut morphology, microbiota composition and volatile short chain fatty acids production of Malaysian Mahseer Tor tambroides. Aquaculture Reports, 9, 53-61.

Bagheri, T., Hedayati, S. A., Yavari, V., Alizade, M., \& Farzanfar, A. (2008). Growth, survival and gut microbial load of rainbow trout (Oncorhynchus mykiss) fry given diet supplemented with probiotic during the two months of first feeding. Turkish Journal of Fisheries and Aquatic Sciences, 8, 43-48.

Balcázar, J. L., Vendrell, D., de Blas, I., Ruiz-Zarzuela, I., Gironés, O., \& Muzquiz, J. L. (2006). Immune modulation by probiotic strains: quantification of phagocytosis of Aeromonas salmonicida by leukocytes isolated from gut of rainbow trout (Oncorhynchus mykiss) using a radiolabelling assay. Comparative Immunology, Microbiology \& Infectious Diseases, 29(5-6), 335-343.

Bandyopadhyay, P., Mishra, S., Sarkar, B., Swain, S. K., Pal, A., Tripathy, P. P., \& Ojha, S. K. (2015). Dietary Saccharomyces cerevisiae boosts growth and immunity of IMC Labeo rohita (Ham.) juveniles. Indian Journal of Microbiology, 55(1), 81-87.

Banerjee, G., Nandi, A., \& Ray, A. K. (2017). Assessment of hemolytic activity, enzyme production and bacteriocin characterization of Bacillus subtilis LR1 isolated from the gastrointestinal tract of fish. Archives of Microbiology, 199(1), $115-124$.

Banerjee, G., \& Ray, A. K. (2017). The advancement of probiotics research and its application in fish farming industries. Research in Veterinary Science, 115, 66-77.

Bondad-Reantaso, M. G., Subasinghe, R. P., Arthur, J. R., Ogawa, K., Chinabut, S., Adlard, R., .. Shariff, M. (2005). Disease and health management in Asian aquaculture. Veterinary Parasitology, 132(3-4), 249-272.

Brogden, G., Krimmling, T., Adamek, M., Naim, H. Y., Steinhagen, D., \& von Köckritz-Blickwede, M. (2014). The effect of $\beta$-glucan on formation and functionality of neutrophil extracellular traps in carp (Cyprinus carpio L). Developmental and Comparative Immunology, 44(2), 280-285.

Browne, M. J., Feng, C. Y., Booth, V., \& Rise, M. L. (2011). Characterization and expression studies of Gaduscidin-1 and Gaduscidin-2; paralogous antimicrobial peptide-like transcripts from Atlantic cod (Gadus morhua). Developmental and Comparative Immunology, 35(3), 399-408.

Burr, G., \& Gatlin, D. M. (2005). Microbial ecology of the gastrointestinal tract of fish and the potential application of prebiotics and probiotics in finfish aquaculture. Journal of the World Aquaculture Society, 36(4), 425-436.

Cardona, E., Gueguen, Y., Magré, K., Lorgeoux, B., Piquemal, D., Pierrat, F., .. Saulnier, D. (2016). Bacterial community characterization of water and intestine of the shrimp Litopenaeus stylirostris in a biofloc system. BMC Microbiology, 16(1), 157

Carnevali, O., Sun, Y. Z., Merrifield, D. L., Zhou, Z., \& Picchietti, S. (2014). Probiotic application in temperate and warm water fish species. In D. Merrifield, \& E. Ringø (Eds.), Aquaculture Nutrition: Gut Health, Probiotics and Prebiotics, (pp. 253-289). Oxford, UK: Wiley-Blackwell Publishing.

Carnevali, O., Zamponi, M. C., Sulpizio, R., Rollo, A., Nardi, M., Orpianesi, C., ... Cresci, A. (2004). Administration of probiotic strain to improve sea bream wellness during development. Aquaculture International, 12(4-5), 377-386.

Chabrillón, M., Arijo, S., Díaz-Rosales, P., Balebonz, M. C., \& Moriñigo, M. A. (2006). Interference of Listonella anguillarum with potential probiotic microorganisms isolated from farmed gilthead seabream (Sparus aurata, L). Aquaculture Research, 37(1), 78-86.

Chi, C., Jiang, B., Yu, X. B., Liu, T. Q., Xia, L., \& Wang, G. X. (2014). Effects of three strains of intestinal autochthonous bacteria and their extracellular products on the immune response and disease resistance of common carp, Cyprinus carpio. Fish and Shellfish Immunology, 36(1), 9-18.

Cordero, H., Morcillo, P., Cuesta, A., Brinchmann, M. F., \& Esteban, M. A. (2016) Differential proteome profile of skin mucus of gilthead seabream (Sparus aurata) after probiotic intake and/or overcrowding stress. Journal of Proteomics, 132, 41-50.

Cruz, P. M., Ibáñez, A. L., Hermosillo, O. A. M., \& Saad, H. C. R. (2012). Use of probiotics in aquaculture. ISRN Microbiology, 916845.

D'Alvise, P. W., Siril Lillebø, M. J., Prol-Garcia, H. I., Wergeland, K. F., Nielsen, Ø. B. \& Lone, G. (2012). Phaeobacter gallaeciensis reduces Vibrio anguillarum in 
cultures of microalgae and rotifers, and prevents vibriosis in cod larvae. PLoS One, 7, 8.

Das, A., Nakhro, K., Chowdhury, S., \& Kamilya, D. (2013). Effects of potential probiotic Bacillus amyloliquifaciens [corrected] FPTB16 on systemic and cutaneous mucosal immune responses and disease resistance of catla (Catla catla). Fish and Shellfish Immunology, 35(5), 1547-1553.

Dawood, M. A. O., \& Koshio, S. (2016). Recent advances in the role of probiotics and prebiotics in carp aquaculture: A review. Aquaculture, 454, 243-251.

Dey, A., Ghosh, K., \& Hazra, N. (2018). Effects of probiotics-encapsulated live feed on growth and survival of juvenile Clarias batrachus (Linnaeus, 1758) after differential exposure to pathogenic bacteria. SAARC Journal of Agriculture, 16(1), 105-113.

Dezfuli, B. S., Giari, L., Lui, A., Lorenzoni, M., \& Noga, E. J. (2011). Mast cell responses to Ergasilus (Copepoda), a gill ectoparasite of sea bream. Fish and Shellfish Immunology, 30(4-5), 1087-1094.

Dohail, A., Abdullah, M., Roshada, H., \& Aliyu-Paiko, M. (2009). Effects of the probiotic, Lactobacillus acidophilus, on the growth performance, haematology parameters and immunoglobulin concentration in African catfish (Clarias gariepinus, Burchell 1822) fingerling. Aquaculture Research, 40(14), 1642-1652.

Egerton, S., Culloty, S., Whooley, J., Stanton, C., \& Ross, R. P. (2018). The Gut Microbiota of Marine Fish. Frontiers in Microbiology, 9, 873.

Elayaraja, S., Annamalai, N., Mayavu, P., \& Balasubramanian, T. (2014). Production, purification and characterization of bacteriocin from Lactobacillus murinus AU06 and its broad antibacterial spectrum. Asian Pacific Journal of Tropical Biomedicine, 4(1), 305-311.

Fei, H., Lin, G. D., Zheng, C. C., Huang, M. M., Qian, S. C., Wu, Z. J., ... Han, B. N. (2018). Effects of Bacillus amyloliquefaciens and Yarrowia lipolytica lipase 2 on immunology and growth performance of Hybrid sturgeon. Fish and Shellfish Immunology, 82, 250-257.

Feliatra, F., Muchlisin, Z. A., Teruna, H. Y., Utamy, W. R., Nursyirwani, N., \& Dahliaty, A. (2018). Potential of bacteriocins produced by probiotic bacteria isolated from tiger shrimp and prawns as antibacterial to Vibrio, Pseudomonas, and Aeromonas species on fish. F1000Research, 7, 415.

Fuller, R. (1989). Probiotics in man and animals. Journal of Applied Bacteriology, 66(5), 365-378.

Fuochi, V., Volti, G. L., Camiolo, G., Tiralongo, F., Giallongo, C., Distefano, A., ... Tibullo, D. (2017). Antimicrobial and anti-proliferative effects of skin mucus derived from Dasyatis pastinaca (Linnaeus, 1758). Marine Drugs, 15, 342.

Gallo, R. L., \& Nakatsuji, T. (2011). Microbial symbiosis with the innate immune defense system of the skin. Journal of Investigative Dermatology, 131(10), 1974-1980

Gatesoupe, J. (1994). Lactic acid bacteria increase the resistance of turbot larvae, Scophthalmus maximus, against pathogenic Vibrio. Aquatic Living Resource, $7(1), 277-282$.

Gatesoupe, J. (1997). Siderophore production and probiotic effect of Vibrio sp. associated with turbot larvae, Scophthalmus maximus. Aquatic Living Resources, 10(4), 239-246.

Ghosh, A., Sinha, A., \& Sahu, C. (2008). Dietary probiotic supplementation in growth and health of live-bearing ornamental fishes. Aquaculture Nutrition, 14(4), 289-299.

Ghosh, K., Banerjee, S., Moon, U. M., Khan, H. A., \& Dutta, D. (2017). Evaluation of gut associated extracellular enzyme-producing and pathogen inhibitory microbial community as potential probiotics in Nile Tilapia, Oreochromis niloticus. International Journal of Aquaculture, 7(23), 143-158.

Ghosh, S., Sinha, A., \& Sahu, C. (2007). Effect of probiotic on reproduction performance in female livebearing ornamental fish. Aquaculture Research, 38(5), 518-526.

Giatsis, C., Sipkema, D., Ramiro-Garcia, J., Bacanu, G. M., Abernathy, J., Verreth, J., ... Verdegem, M. (2016). Probiotic legacy effects on gut microbial assembly in tilapia larvae. Scientific Reports, 6, 33965.

Gioacchini, G., Valle, D. L., Benato, F., Fimia, G. M., Nardacci, R., Ciccosanti, F., ... Carnevali, O. (2013). Interplay between autophagy and apoptosis in the development of Danio rerio follicles and the effects of a probiotic. Reproduction, Fertility and Development, 25(8), 1115-1125.

Giri, S. S., Sukumaran, V., \& Oviya, M. (2013). Potential probiotic Lactobacillus plantarum VSG3 improves the growth, immunity, and disease resistance of tropical freshwater fish, Labeo rohita. Fish and Shellfish Immunology, 34(2), 660-666.

Gisbert, E., Castillo, M., Skalli, A., Andree, K. B., \& Badiola, I. (2013). Bacillus cereus var. toyoi promotes growth, affects the histological organization and microbiota of the intestinal mucosa in rainbow trout fingerlings. Journal of Animal Science, 91(6), 2766-2774.

Gomez, D., Sunyer, J. O., \& Salinas, I. (2013). The Mucosal immune system of fish: The evolution of tolerating commensals while fighting pathogens. Fish and Shellfish Immunology, 35(6), 1729-1739.

Gram, L., Melchiorsen, J., Spanggaard, B., Huber, I., \& Nielsen, T. (1999). Inhibition of Vibrio anguillarum by Pseudomonas fluorescence strain $\mathrm{AH} 2$-a possible probiotic treatment of fish. Applied and Environmental Microbiology, 65(3), 969-973.

Hai, N. V. (2015). Research findings from the use of probiotics in tilapia aquaculture: a review. Fish and Shellfish Immunology, 45(2), 592-597.

Hamdan, A. M., El-Sayed, A. F., \& Mahmoud, M. M. (2016). Effects of a novel marine probiotic, Lactobacillus plantarum $\mathrm{AH} 78$, on growth performance and immune response of Nile tilapia (Oreochromis niloticus). Journal of Applied Microbiology, 120(4), 1061-1073.

Han, B., Long, W. Q., He, J. Y., Liu, Y. J., Si, Y. Q., \& Tian, L. X. (2015). Effects of dietary Bacillus licheniformison growth performance, immunological parameters, intestinal morphology and resistance of juvenile Nile tilapia (Oreochromis niloticus) to challenge infections. Fish and Shellfish Immunology, 46(2), 225-231.

Harikrishnan, R., Balasundaram, C., \& Heo, M. S. (2010). Effect of probiotics enriched diet on Paralichthys olivaceus infected with lymphocystis disease virus (LCDV). Fish and Shellfish Immunology, 29(5), 868-874.

Hasan, K. N., Moniruzzaman, M., \& Maitra, S. K. (2014). Melatonin concentrations in relation to oxidative status and oocyte dynamics in the ovary during different reproductive phases of an annual cycle in carp Catla catla. Theriogenology, 82(8), 1173-1185.

Hasan, K. N., Pal, P. K., \& Maitra, S. K. (2020). Temporal relationship between the levels of melatonin and different antioxidants in the liver of a surface feeding carp Catla catla. Biological Rhythm Research, 51(3), 373-391.

He, S., Ran, C., Qin, C., Li, S., Zhang, H., de Vos, W. M., ... Zhou, Z. (2017). Antiinfective effect of adhesive probiotic Lactobacillus in fish is correlated with their spatial distribution in the intestinal tissue. Scientific Reports, 7(1), 13195

Hoseinifar, S. H., Ringø, E., Masouleh, A. S., \& Esteban, M. A. (2016). Probiotic, prebiotic and synbiotic supplements in sturgeon aquaculture: a review. Reviews in Aquaculture, 8(1), 89-102.

Ige, B. A. (2013). Probiotics use in intensive fish farming. African Journal of Microbiology, 7, 2701-2711.

Irianto, A., \& Austin, B. (2002). Probiotics in aquaculture. Journal of Fish Diseases, 25(11), 633-642.

Jiang, H. F., Liu, X. L., Chang, Y. Q., Liu, M. T., \& Wang, G. X. (2013). Effects of dietary supplementation of probiotic Shewanella colwelliana WA64, Shewanella olleyana WA65 on the innate immunity and disease resistance of abalone, Haliotis discus hannai Ino. Fish and Shellfish Immunology, 35(1), 86-91.

Jiang, Y., Zhang, Z., Wang, Y., Jing, Y., Liao, M., Rong, X., ... Zhang, H. (2018), Effects of probiotic on microfloral structure of live feed used in larval breeding of turbot Scophthalmus maximus. Journal of Oceanology and Limnology, 36(3), 1002-1012.

Kalarani, V., Sumathi, V., Roshan, J. K., Sowjanya, D., \& Reddy, D. C. (2016). Effect of dietary supplementation of Bacillus subtilis and Terribacillus saccharophillus on innate immune responses of a tropical freshwater fish, Labeo rohita. Journal of Clinical and Cellular Immunology, 7, 395.

Kelly, C., \& Salinas, I. (2017). Under pressure: Interactions between commensal microbiota and the teleost immune system. Frontiers in Immunology, 8, 559.

Kesarcodi-Watson, A., Kaspar, H., Lategan, M. J., \& Gibson, L. (2008). Probiotics in aquaculture: The need, principles and mechanisms of action and screening processes. Aquaculture, 274(1), 1-14.

Kozasa, M. (1986). Toyocerin (Bacillus toyoi) as growth promoter for animal feeding. Microbiologie, Aliments, Nutrition, 4, 121-135.

Lakshmi, B., Viswanath, B., \& Sai Gopal, D. V. (2013). Probiotics as antiviral agents in shrimp aquaculture. Journal of Pathogens, 2013, 424123.

Lara-Flores, M., \& Olvera-Novoa, M. A. (2013). The use of lactic acid bacteria isolated from intestinal tract of Nile tilapia (Oreochromis niloticus), as growth promoters in fish fed low protein diets. Latin American Journal of Aquatic Research, 41(3), 490-497.

Lazado, C. C., \& Caipang, C. M. A. (2014). Mucosal immunity and probiotics in fish. Fish and Shellfish Immunology, 39, 78-89.

Lazado, C. C., Caipang, C. M. A., Brinchmann, M. F., \& Kiron, V. (2011). In vitro adherence of two candidate probiotics from Atlantic cod and their interference with the adhesion of two pathogenic bacteria. Veterinary Microbiology, 148(2-4), 252-259. 
Liang, Y., Guan, R., Huang, W., \& Xu, T. (2011). Isolation and identification of a novel inducible antibacterial peptide from the skin mucus of Japanese eel, Anguilla japonica. The Protein Journal, 30(6), 413-421.

Liu, C. H., Chiu, C. H., Wang, S. W., \& Cheng, W. (2012). Dietary administration of the probiotic, Bacillus subtilis E20, enhances the growth, innate immune responses, and disease resistance of the grouper, Epinephelus coioides. Fish and Shellfish Immunology, 33(4), 699-706.

Liu, S., Du, Y., Sheng, X., Tang, X., Xing, J., \& Zhan, W. (2019). Molecular cloning of polymeric immunoglobulin receptor-like (plgRL) in flounder (Paralichthys olivaceus) and its expression in response to immunization with inactivated Vibrio anguillarum. Fish and Shellfish Immunology, 87, 524-533.

Lobo, C., Moreno-Ventas, X., Tapia-Paniagua, S., Rodríguez, C., Morinigo, M. A., \& de La Banda, I. G. (2014). Dietary probiotic supplementation (Shewanella putrefaciens Pdp11) modulates gut microbiota and promotes growth and condition in Senegalese sole larviculture. Fish Physiology and Biochemistry, 40(1), 295-309.

Lukwambe, B., Qiuqian, L., Wu, J., Zhang, D., Wang, K., \& Zheng, Z. (2015). The effects of commercial microbial agents (probiotics) on phytoplankton community structure in intensive white shrimp (Litopenaeus vannamei) aquaculture ponds. Aquaculture International, 23(6), 1443-1455.

Mackenzie, D. A., Jeffers, F., Parker, M. L., Vibert-Vallet, A., Bongaerts, R. J., Roos, S., ... Juge, N. (2010). Strain-specific diversity of mucus-binding proteins in the adhesion and aggregation properties of Lactobacillus reuteri. Microbiology, 156(11), 3368-3378.

Makridis, P., Fjellheim, A. J., Skjermo, J., \& Vadstein, O. (2000). Colonization of the gut in first feeding turbot by bacterial strains added to the water or biencapusated in rotifers. Aquaculture International, 8(5), 367-380.

Martínez Kathia, C., María del Carmen, M. D., Aida, H. P., Jorge, C. M., José Félix, A. G., \& Jaime Amadeo, B. M. (2018). Effect of two probiotics on bacterial community composition from biofloc system and their impact on survival and growth of tilapia (Oreochromis niloticus). International Journal of Fisheries and Aquatic Studies, 6(2), 525-533.

Melgar Valdes, C. E., Barba Macías, E., Alvarez-González, C. A., Tovilla Hernández, C. , \& Sánchez, A. J. (2013). Microorganisms effect with probiotic potential in water quality and growth of the shrimp Litopenaeus vannamei (Decapoda: Penaeidae) in intensive culture. Revista de Biología Tropical, 61(3), 1215-1228.

Merrifield, D. L., \& Carnevali, O. (2014). Probiotic modulation of the gut microbiota of fish. In D. L. Merrifield, \& E. Ringø (Eds.), Aquaculture Nutrition: Gut Health, Probiotics and Prebiotics, (pp. 185-222). Oxford, UK: WileyBlackwell Publishing.

Merrifield, D. L., Dimitroglou, A., Foey, A., Davies, S. J., Baker, R. T. M., Bøgwald, J., Castex, M., \& Ringø, E. (2010a). The current status and future focus of probiotic and prebiotic applications for salmonids. Aquaculture, 302(1-2), 118.

Merrifield, D. L., Harper, G. M., Dimitroglou, A., Ringø, E., \& Davies, S. J. (2010b). Possible influence of probiotic adhesion to intestinal mucosa on the activity and morphology of rainbow trout (Oncorhynchus mykiss) enterocytes. Aquaculture Research, 41(8), 1268-1272.

Mirghaed, A. T., Yarahmadi, P., Hosseinifar, S. H., Tahmasebi, D., Gheisvandi, N., \& Ghaedi, A. (2018). The effects singular or combined administration of fermentable fiber and probiotic on mucosalimmune parameters, digestive enzyme activity, gut microbiota and growth performance of Caspian white fish (Rutilus frisii kutum) fingerlings. Fish and Shellfish Immunology, 77, 194-199.

Modanloo, M., Soltanian, S., Akhlaghi, M., \& Hoseinifar, S. H. (2017). The effects of single or combined administration of galactooligosaccharide and Pediococcus acidilactici on cutaneous mucus immune parameters, humoral immune responses and immune related genes expression in common carp (Cyprinus carpio) fingerlings. Fish and Shellfish Immunology, 70, 391-397.

Mujeeb Rahiman, K., Yousuf, J., Thomas, A. P., \& Hatha, M. (2010). Probiotic effect of Bacillus NL110 and Vibrio NE17 on the survival, growth performance and immune response of Macrobrachium rosenbergii (de Man). Aquaculture Research, 41(9), 120-134

Munang'andu, H. M., Mutoloki, S., \& Evensen, $\varnothing$. (2015). An overview of challenges limiting the design of protective mucosal vaccines for finfish. Frontiers in Immunology, 6, 542.

Munirasu, S., Ramasubramanian, V., \& Arunkumar, P. (2017). Effect of probiotics diet on growth and biochemical performance of freshwater fish Labeo rohita fingerlings. Journal of Entomology and Zoology Studies, 5(3), 1374-1379.

Nandi, A., Banerjee, G., Dan, S. K., Ghosh, K., \& Ray, A. K. (2018). Evaluation of in vivo probiotic efficiency of Bacillus amyloliquefaciens in Labeo rohita challenged by pathogenic strain of Aeromonas hydrophila MTCC 1739. Probiotics and Antimicrobial Proteins, 10(2), 391-398.

NavinChandran, M., Iyapparaj, P., Moovendhan, S., Ramasubburayan, R., Prakash, S., Immanuel, G., \& Palavesam, A. (2014). Influence of probiotic bacterium Bacillus cereus isolated from the gut of wild shrimp Penaeus monodon in turn as a potent growth promoter and immune enhancer in $P$. monodon. Fish and Shellfish Immunology, 36(1), 38-45.

Nayak, S. K. (2010). Role of gastrointestinal microbiota in fish. Aquaculture Research, 41(11), 1553-1573.

Newaj-Fyzul, A., Adesiyunz, A. A., Mutani, A., Ramsudhag, A., Brunt, J., \& Austin, B. (2007). Bacillus subtilis AB1 controls Aeromonas infection in rainbow trout (Oncorhynchus mykiss, Walbaum). Journal of Applied Microbiology, 103(5), 1699-1706.

Newaj-Fyzul, A., Al-Harbi, A. H., \& Austin, B. (2014). Review: Developments in the use of probiotics for disease control in aquaculture. Aquaculture, 431, 1-11.

Nikoskelainen, S., Ouwehand, A. C., Bylund, G., Salminen, S., \& Lilius, E. M. (2003). Immune enhancement in rainbow trout (Oncorhynchus mykiss) by potential probiotic bacteria (Lactobacillus rhamnosus). Fish and Shellfish Immunology, 15(5), 443-452.

Padmavathi, P., Sunitha, K., \& Veeraiah, K. (2012). Efficacy of probiotics in improving water quality and bacterial flora in fish ponds. African Journal of Microbiology Research, 6(49), 7471-7478.

Pandiyan, P., Balaraman, D., Thirunavukkarasu, R., George, E. G. J., Subaramaniyan, K., Manikkam, S., \& Sadayappan, B. (2013). Probiotics in aquaculture. Drug Invention Today, 5(1), 55-59.

Panigrahi, A., Kiron, V., Satoh, S., \& Watanabe, T. (2010). Probiotic bacteria Lactobacillus rhamnosus influences the blood profile in rainbow trout Oncorhynchus mykiss (Walbaum). Fish Physiology and Biochemistry, 36(4), 969-977.

Picchietti, S., Mazzini, M., Taddei, A. R., Renna, R., Fausto, A. M., Mulero, V., ... Abelli, L. (2007). Effects of administration of probiotic strains on GALT of larval gilthead seabream: immunohistochemical and ultrastructural studies. Fish and Shellfish Immunology, 22(1-2), 57-67.

Porubcan, R. S. (1991). Reduction of ammonia nitrogen and nitrite in tanks of Penaeus monodon using floating biofilters containing processed diatomaceous earth media pre-inoculated with nitrifying bacteria. Proceedings of the Program and 22nd Annual Conference and Exposition, (pp. 16-20). Puerto Rico: World Aquaculture Society.

Priyodip, P., Prakash, P. Y., \& Balaji, S. (2017). Phytases of probiotic bacteria: Characteristics and beneficial aspects. Indian Journal of Microbiology, 57(2), $148-154$.

Pybus, V., Loutit, M. W., Lamont, I. L., \& Tagg, J. R. (1994). Growth inhibition of the salmon pathogen Vibrio ordalii by a siderophore produced by Vibrio anguillarum strain VL4335. Journal of Fish Diseases, 17(4), 311-324.

Qi, Z., Zhang, X. H., Boon, N., \& Bossier, P. (2009). Probiotics in aquaculture of China-Current state, problems and prospect. Aquaculture, 290(1-2), 15-21.

Ringø, E., Dimitroglou, A., Hoseinifar, S. H., \& Davies, S. J. (2014). Prebiotics in finfish: an update. In D. L. Merrifield, \& E. Ringø (Eds.), Aquaculture Nutrition: Gut Health, Probiotics and Prebiotics, (pp. 360-400). Oxford, UK: WileyBlackwell Publishing.

Ringø, E., Hoseinifar, S. H., Ghosh, K., Van Doan, H., Beck, B. R., \& Song, S. K. (2018). Lactic acid bacteria in finfish-an update. Frontiers in Microbiology, 9, 1818.

Roeselers, G., Mittge, E. K., Stephens, W. Z., Parichy, D. M., Cavanaugh, C. M., Guillemin, K., \& Rawls, J. F. (2011). Evidence for a core gut microbiota in the zebrafish. ISME Journal, 5(10), 1595-1608.

Ruangsri, J., Lokesh, J., Fernandes, J. M. O., \& Kiron, V. (2014). Transcriptional regulation of antimicrobial peptides in mucosal tissues of Atlantic cod Gadus morhua L. in response to different stimuli. Aquaculture Research, 45(12), 1893-1905.

Safari, R., Hoseinifar, S. H., Dadar, M., \& Khalili, M. (2018). Powder of the white bottom mushroom, Agaricus bisporus (Agaricomycetes), improved immunomodulatory and health-promoting effects of Lactobacillus casei in zebrafish (Danio rerio). International Journal of Medicinal Mushrooms, 20(7), 695-704.

Sahu, M. K., Swarnakumar, N. S., Sivakumar, K., Thangaradjou, T., \& Kannan, L. (2008). Probiotics in aquaculture: importance and future perspectives. Indian Journal of Microbiology, 48(3), 299-308.

Salinas, I. (2015). The mucosal immune system of teleost fish. Biology, 4(3), 525-539.

Salinas, I., Abelli, L., Bertoni, F., Picchietti, S., Roque, A., Furones, D., ... Esteban, M. A. (2008). Monospecies and multispecies probiotic formulations produce different systemic and local immunostimulatory effects in the gilthead seabream (Sparus aurata L.). Fish and Shellfish Immunology, 25(1-2), 114-123. 
Salinas, I., Zhang, Y. A., \& Oriol Sunyer, J. (2011). Mucosal immunoglobulins and B cells of teleost fish. Developmental and Comparative Immunology, 35(12), 1346-1365.

Sánchez-Ortiz, A. C., Luna-González, A., Campa-Córdova, A. I., Escamilla-Montes, R., Flores-Miranda, M. D. C., \& Mazón-Suástegui, J. M. (2015). Isolation and characterization of potential probiotic bacteria from pustulose ark (Anadara tuberculosa) suitable for shrimp farming. Latin American Journal of Aquatic Research, 43(1), 123-136.

Sangma, T., \& Kamilya, D. (2015). Dietary Bacillus subtilis FPTB13 and chitin, single or combined, modulate systemic and cutaneous mucosal immunity and resistance of catla, Catla catla (Hamilton) against edwardsiellosis. Comparative Immunology, Microbiology and Infectious Diseases, 43, 8-15.

Sayes, C., Leyton, Y., \& Riquelme, C. (2018). Probiotic bacteria as a healthy alternative for fish aquaculture. In S. Savic (Ed.), Antibiotics use in animals, (pp. 115-132). Rijeka: InTech Publishers.

Schmidt, V., Gomez-Chiarri, M., Roy, C., Smith, K., \& Amaral-Zettler, L. (2017). Subtle microbiome manipulation using probiotics reduces antibiotic-associated mortality in fish. mSystems, 2(6), e00133-e00117.

Seo, J. M., Lee, M. J., Go, H. J., Park, T. H., \& Park, N. G. (2012). Purification and characterization of YFGAP, a GAPDH-related novel antimicrobial peptide, from skin of yellowfin tuna, Thunnus albacores. Fish and Selfish Immunology, 33, 743-752.

Subasinghe, R. P. (2005). Epidemiological approach to aquatic animal health management: opportunities and challenges for developing countries to increase aquatic production through aquaculture. Preventive Veterinary Medicine, 67(2-3), 117-124

Sugita, H., Mizuki, H., \& Itoi, S. (2012). Diversity of siderophore-producing bacteria isolated from the intestinal tracts of fish along the Japanese coast. Aquaculture Research, 43(4), 481-488.

Sunitha, K., \& Krishna, P. V. (2016). Efficacy of probiotics in water quality and bacterial biochemical characterization of fish ponds. International Journal of Current Microbiology and Applied Sciences, 5(9), 30-37.

Talpur, A. D., Memon, A. J., Khan, M. I., Ikhwanuddin, M., Abdullah, M. D. D., \& Bolong, A. M. A. (2013). Gut Lactobacillus sp. bacteria as probiotics for Portunus pelagicus (Linnaeus, 1758) larviculture: effects on survival, digestive enzyme activities and water quality. Invertebrate Reproduction and Development, 57(3), 173-184

Tan, L. T., Chan, K. G., Lee, L. H., \& Goh, B. H. (2016). Streptomyces bacteria as potential probiotics in aquaculture. Frontiers in Microbiology, 7, 79.

Taoka, Y., Yuge, K., Maeda, H., \& Koshio, S. (2008). The efficiency of Lactobacillus plantarum in diet for juvenile Japanese flounder Paralichthys olivaceus reared in a closed recirculating system. Aquaculture Science, 56(2), 193-202.

Tarnecki, A. M., Wafapoor, M., Phillips, R. N., \& Rhody, N. R. (2019). Benefits of a Bacillus probiotic to larval fish survival and transport stress resistance. Scientific Reports, 9(1), 1-11.

Thakur, N., Rokana, N., \& Panwar, H. (2016). Probiotics: Selection criteria, safety and role in health and disease. Journal of Innovative Biology, 3(1), 259-270.

Vadstein, O., Attramadal, K. J., Bakke, I., Forberg, T., Olsen, Y., Verdegem, M., .. Dierckens, K. (2018). Managing the microbial community of marine fish larvae: a holistic perspective for larviculture. Frontiers in Microbiology, 9, 1820.

Van Doan, H., Hoseinifar, S. H., Dawood, M. A. O., Chitmanat, C., \& Tayyamath, K. (2017). Effects of Cordyceps militaris spent mushroom substrate and Lactobacillus plantarum on mucosal, serum immunology and growth performance of Nile tilapia (Oreochromis niloticus). Fish and Shellfish Immunology, 70, 87-94

Verschuere, L., Rombaut, G., Sorgeloos, P., \& Verstraete, W. (2000). Probiotic bacteria as biological control agents in aquaculture. Microbiology and Molecular Biology Reviews, 64(4), 655-671.

Vine, N. G., Leukes, W. D., \& Kaiser, H. (2006). Probiotics in marine larviculture. FEMS Microbiology Reviews, 30(3), 404-427.

Wang, A. L., Zheng, G. L., Liao, S. A., Huang, H. H., \& Sun, R. Y. (2007). Diversity analysis of bacteria capable of removing nitrate/nitrite in a shrimp pond. Acta Ecologica Sinica, 27(5), 1937-1943.

Wang, Y., Ren, Z., Fu, L., \& Su, X. (2016). Two highly adhesive lactic acid bacteria strains are protective in zebrafish infected with Aeromonas hydrophila by evocation of gut mucosal immunity. Journal of Applied Microbiology, 120(2), $441-451$.

Wang, Y. M., \& Wang, Y. G. (2008). Advance in the mechanisms and application of microecologics in aquaculture. Progress in Veterinary Medicine, 29, 72-75.

Wu, Z. Q., Jiang, C., Ling, F., \& Wang, G. X. (2015). Effects of dietary supplementation of intestinal autochthonous bacteria on the innate immunity and disease resistance of grass carp (Ctenopharyngodon idellus). Aquaculture, 438, 105-114.

Zhou, Q. C., Buentello, J. A., \& Gatlin, D. M. (2010). Effects of dietary prebiotics on growth performance, immune response and intestinal morphology of red drum (Sciaenops ocellatus). Aquaculture, 309(1-4), 253-257.

Zolotukhin, P. V., Prazdnova, E. V., \& Chistyakov, V. A. (2018). Methods to assess the antioxidative properties of probiotics. Probiotics and Antimicrobial Proteins, 10(3), 589-599.

\section{Publisher's Note}

Springer Nature remains neutral with regard to jurisdictional claims in published maps and institutional affiliations.

\section{Submit your manuscript to a SpringerOpen ${ }^{\circ}$ journal and benefit from:}

- Convenient online submission

- Rigorous peer review

- Open access: articles freely available online

- High visibility within the field

- Retaining the copyright to your article

Submit your next manuscript at $\boldsymbol{\nabla}$ springeropen.com 